ISSN 1112-9867

\title{
INVESTIGATING THE CHARACTERISTICS OF SHAHRIAR'S POETRY
}

\author{
F. Mina
}

$\mathrm{PhD}$ in Persian Language and Literature, lecturer at Shahid Bahonar University

Published online: 15 May 2016

\begin{abstract}
Seyed Mohammad Hossein Bahjat Tabrizi, known as Shahriar, was born in 1906 in Tabriz. He was one of the poets who composed poetry in different formats, but he is best known for his Ghazals. After a review of Shahriar's life, this paper briefly explores his language and poetic style. Then, the relationship between his poem and verses of Quran and his devotion to the Imams (PBUH) will be investigated. Another issue discussed in this article is his interest in the poets before him and imitation of their styles. He had a special devotion to Hafez Shirazi and composition of some of his poems was inspired by Hafez poems. That is because his association with Hafez poems improved the vitality of his poems.
\end{abstract}

Keywords: Shahriar; language; style of poetry; verses of Quran; Hafez.

Author Correspondence, e-mail: mina.fatemeh@yahoo.com

doi: http://dx.doi.org/10.4314/jfas.v8i3s.236

\section{INTRODUCTION}

Seyed Mohammad Hossein Behjat Tabrizi, known as Shahriar, son of Seyed Esmail Mousavi known as Hajmiragha Khoshknabi, was born in 1906 in Tabriz. His father, Hajmiragha Khoshknabi, was a lawyer in Tabriz. Shahriar's childhood coincided with the events of the constitutional revolution, war, and insecurity in the country. Hajmiragha and the family moved to the village of Qare Qushaq in Gharechaman due to unsafe political situation of the city. 
After the chaos in Tabriz had ended, Shahriar returned to the city and completed his studies in Muhammadiyah near Tabriz. He then moved to Tehran in 1921 to continue his studies and found a lot of friends there.

Shahriar's Father encouraged him to study sciences of the time, particularly medicine and this caused Shahriar to study medicine in Dar-ol-Fonoun (former higher education school) in Tehran, but after five years of study there, he dropped out after he had fallen in love and could not complete his education there. He then moved to Neyshabur, where he worked in Registration Department.

During his stay in Neyshabur, Mashhad (1932-33) he participated in literary meetings in Khorasan. At the end of his mission in Khorasan, he returned to Tehran and was employed in the Agricultural Bank with the help of his friend, Ismail Amirkhizi. Shahriar did not like Tehran because he didn't have a good memory thereof, but his compulsory residence in Tehran and familiarity with poetry and literature there led to creation of valuable and influential works by him. After the death of his parents, he decided to return to his homeland, Tabriz due to homesickness and insecurity in Tehran. He married a girl of his relatives and started publishing his works with the encouragement of his friends.

Professor Shahriar passed away on September 18, 1988 in Mehr Hospital in Tehran, after a lifetime endeavor to promote culture and literature of his homeland. He was buried in Maqbaratoshoara of Tabriz.

In this study, after describing the characteristics of Shahriar's poems, the most important themes in his poetry are mentioned. This include the use of language and slang in his poems; application of specific musical terms; attention to the Quran and Ahl al-Bayt and special devotion to them; imitation of the words of Hafiz; etc.

\subsection{Selecting the pseudonym «Shahriar»}

Shahriar first composed his poems under the given name, Behjat. After thirty three years living away from his hometown and going through many hardships. One night, he prayed God and then sought help from Khajeh of Shiraz through "Hafez readings" (fāl-e hāfez). He openned Hafez's Divan and saw a sonnet of Hafiz, which led to a huge change in his life. He selected the pen name "Shahriar" then and decided to return to his hometown. A couplet in the exquisite sonnet leading to that significant change in his life is as follows:

Ghame gharibi -o- ghorbat cho bar nemitabam 
Since I cannot tolerate the sorrow of estrangement

Be shahre khod ravam-o- shahriare khod basham

I'll return to my hometown and become Shahriar (Hafez Divan, 2008).

\section{CHARACTERISTICS OF SHAHRIAR'S POEMS}

Attractive, simple, and eloquent expression is among features of Shahriar's poems. Of course, sometimes it is observed that the poet uses even slang terms alongside subtle and literary expression and blends beautiful rhetoric images with colloquial language.

Shahriar used his impressionable soul and poetic talent to express his emotions, imagination, and ideas in the language of ordinary people. This is why his poem is familiar and effective for all. He has composed poetry in different styles, but the elegance and simplicity of language is seen more in his Ghazals. Another characteristic of Shahriar was that he was a fluent bilingual and composed lasting poems in two languages (Persian and Turkish).

Certainly, Shahriar's reputation cannot be just attributed to his Persian poems, but also to his Turkish poems especially Heydar Babaya Salam, which has had a tremendous impact on promoting Shahriar's reputation. This poem extended his reputation to the farthest corners of the world and increased his value in the eyes of people.

\subsection{Shahriar's Ghazals}

Much of the Shahriar's peoms are in the form of Ghazal. Publicity and simplicity of language and interpretation are among the factors led to the popularity of his poems. "His language, as mentioned, follows the criteria of simplicity and closeness to nature" (Monzavi, 1993). Shahriar is mostly known for his Ghazals. It is not just the elegance, simplicity of expression, and the use of some literary techniques that have mad his Ghazals reputable, but also the poet added to dynamics of his poems by resorting to some other measures, some of which are discussed below:

\subsubsection{The use of colloquial language in poems}

One of the characteristics of Shahriar's poems is the use of colloquial language. According to Musharraf, application of such language adds to the quality of his poems since "colloquial language, regardless of its hobby effects, has some other benefits, including preservation of proverbs and expression styles popular among the people of an age" (Musharraf, 2003).

For example, in the following couplets, he used colloquial expressions of "telo telo khordan" (to stumble), "velo shodan" (to fall down), and .... 
Ba khalgh mikhori mey-o- baa maa telo telo

You drink wine with people but stumble when accompanying me

Ghorbane har che bacheye khobe sarash besho

I love all obedient wise friends

Bavar nadashtam ke be in zoodi ey faghir

I did not believe that you poor so soon,

Dar zire dasto paye harifan shavi velo

Become laid down under the feet of others (Shahriar's Divan, 1968)

\subsubsection{Music and instruments in Shahriar's language}

Another factor that plays a role in making the poetry of Shahriar distinguished among other poets is the inclusion of music in his poetry. His familiarity with music had a great influence on his poetry. Some words can be found in his pleasant poems that reflect his interest in music and his awareness of melodies and musicality. For example, in the following couplet, the poet speaks of playing an instrument:

Bezan ke sooze dele man be saaz migooei

Play the instrument as if you tell it my passions

Ze saze del che shenidi ke baaz migooei

What did you hear from my heart that you are restating?

(Shahriar's Divan, 1968)

In the following couplet, the poet talks about his instrument, "Setar".

Nalad be hale zaare man emshab setare man

My setar is crying for my misery tonight

Ein maye tasali shabhaye tar-e- man

It is the comfort of my dark nights

(Shahriar's Divan, 1968)

Music not only gave a new spirit to Shahriar's poetry, but also changed his life. Shahriar played the instrument with an especial passion and unique manner. For this reason, Saba told him: "You have a fire in your soul that no one has had before" (Mazinani, 2001).

\subsubsection{Shahriar's devotion to Quran}

Shahriar was fond of Quran from the very childhood and manifestation of his devotion to this scripture is clearly visible in his poems. In addition to the two aesthetically pleasing odes, "the 
book of God" and "the writing of the Quran" composed on Quran dignity, his use of Quranic and religious knowledge can be seen in his Ghazals, odes, and Masnavis.

Here are some examples of these poems.

For example, attention to this verse from Quran is seen in the following couplet: "I smell the scent of Joseph, unless you think I am foolish. But, (those around him) said: by Allah, ' they said, 'this is but your old illusion (Joseph / 95-94)."

Ashamo Raehata Yusufi va Kaifa shamim

I can smell the scent of my Joseph and what a scent it is

Ajab ke baz nemi ayam az zalale ghadim

It's surprising that I cannot come out of my old illusion

Asir-e- beit-e- hozn goo dariche ha bogsha

Tell the captive of the prison of sorrow, open the windows

Ashamo Raehata Yusufi va Kaifa shamim

I can smell the scent of my Joseph and what a scent it is

(Shahriar's Divan, 1968).

Reference to the verse "... victory from Allah and a conquest that is near..." (Saf / 13) can be seen in the following couplet:

Aan ghahreman ke "Nasro mena Allah" sepahe oost

That hero whose army is "victory from Allah"

Khosh dad doosh mozhde "Fath-e- Ghariib"

Gave me the good news of "a near conquest" last night

(Shahriar's Divan, 1968).

\subsubsection{Devotion to Prophet Muhammad's family (Ahl al-Bayt)}

The love of Ahl al-Bayt, especially Imam Ali (AS) is clearly manifested in the poems of Shahriar and this has appealed to lovers of Ahl al-Bayt (AS). Poems like Ali and Night; Ali, a Perfect Man, Velayat, Ali ey Homay-e- Rahmat, and the Sun and Moon of Velayat are examples. But the poem Homay-e- Rahmat (the bird of bliss) has a particular distinction and brilliance, because, it appears fresher and more interesting than before even with the passage of time. It never looks ancient in the eyes of lovers of poetry and literature. Here are a few lines this Ghazal. O Ali! the bird of bliss, what a portent of God thou art For, thy shadow hast over-shadowed One and all 
O heart! If thou art Gog-gnostic, seek every thing in Ali`s image

By God, I came to know God by the very Ali indeed

\subsubsection{Shahriar and Hafez}

Shahriar has been familiar with Hafez from childhood. He deemed the "voice" of Hafez as calming alongside that of the holy Quran. The depth of the relationship and similarities between the two renowned poets are to the extent that requires separate discussions. The most obvious manifestation of this relationship is the selection of the pseudonym "Shahriar" from the Divan of Hafez.

Shahriar's spiritual connection with Hafez is evident in his poems as he states his devotion to Hafez in the following couplet.

Hafza cheshme eshraghe to javidan ast

O! Hafez you are the immortal source of illumination

Ta abad aab az in cheshme ravan khahad bood

Water will always flow from this spring forever

(Shahriar's Divan, 1968).

Safar mapasand hargez shahriar az maktabe Hafez

Never think of a departure from Hafez's school of thought

Ke seir manavi inja va konje khanghah inja

As both the spiritual journey and the monastery are here

(Shahriar's Divan, 1968).

Sometimes imitation of Hafez adorns his poems:

\section{Hafez:}

Hasale Kargahe kowno makaan in hame nist / Baade pish aar ke asbabe jahan inhame nist (Hafez's Divan, 2008)

The produce of the workshop of existence and dwelling all is naught;

Bring wine. For the goods of the world all is naught.

\section{Shahriar:}

Ta bovad khoone jegar khane jahan in hame nist / Baade pish aar ke asbabe jahan inhame nist As long as there are all these hardships, the world's feast is naught;

Bring wine. For the goods of the world all is naught.

(Shahriar's Divan, 1968) 


\section{SHAHRIAR'S VIES REGARDING THE POWER OF POEMS}

Shahriar believes that the poem should compose the flow of poems relying on God-bestowed "talent" to manifest the spirit of poetry with more intimacy. This way, the poet can convey his feelings to the readers well and cause a change in them. In this regard, Shahriar writes:

"My advice to young poets is that, instead of occupation with all these literary schools of the world, they start reading the masterpieces of world literature and compose their own poems. They should be confident that the God-given talent and initiative of the poet is a creative power that knows how to create poetry and in what form and color" (Musharraf, 2003).

The most important criterion for eternity of poems is the impact of the poet's words on the readers' soul. If poems are associated with internal ferment, love, and art, it will have a lasting effect on the hearts of readers. Malek o-Sho'arā Bahar defines real poetry as follows:

Sher aan bashad ke khizad az del-o- jooshad ze lab

Real she'r is the one that rises from the heart and flows out of the lips

Baaz dar delha neshinad har koja gooshi shenoft

And finds its way to the hearts wherever it is heard (Amini, 1976).

\section{CONCLUSION}

Poems can become immortal if they arise out of the poet's God-given feelings and talents. This way, they can even revitalize dead souls bereft of artistic talent. Shahriar is one of the poets whose poems contain this basic characteristic of good poetry.

Another characteristic of Shahriar's poems is that sorrow and pain are observed in his words concordant with the sorrow of society. He is one of the poets who composed poems in all poetic forms such as ode, Masnavi, Ghazal, etc. The major purpose of this paper was investigation of characteristics of Shahriar's poems. Most of these characteristics are evident in his Ghazals. That's why Shahriar is known by his Ghazals. Another factor that has made his poems especially his Ghazals lasting, is the use of colloquial language of ordinary people, and reference to Quranic verses and religious teachings. Moreover, use of music with his poetry and knowledge of music terminology has given a penetrating effect to his words. One of the most important factors that create movement and vitality in Shahriar's language is reference to Hafez's poets; because, as pointed out repeatedly by Shahriar, paying attention to Quran and Hafez poems played a significant role in his progress in poetry. 


\section{REFERENCES}

[1] Amini, D. (2000). The story of Shahriar's life and spiritual journey. Qom: Nasmie Hayat. First Edition.

[2] Hafez, Khajeh Shams al-Din Muhammad. (2008). Divan-e-Hafez. Corrected by Mohammad Qazvini and Qasem Ghani. Tehran: Farhang-o-Ghalam. Eighth Edition.

[3] Shahriar (Behjat Tabrizi), M. (1968). Shahriar's Divan. Corrected by Shahriar. Tabriz: Saadi Publications. Second edition.

[4] Mazinani, M. K. (2001). Shahriar. Tehran: Madrese. First Edition.

[5] Musharraf, M. (2007). The heaven's bird: life and poetry of Mohammad Hossein Shahriar. Tehran: Sales Publication. Second Edition.

[6] Monzavi, H. (1993). Shahriar, the poet of passion and eloquence. Tehran: Barg. First Edition.

How to cite this article:

Mina F. Investigating the characteristics of Shahriar's poetry. J. Fundam. Appl. Sci., 2016, 8(3S), 544-551. 